\title{
Empirical Analysis of Factors Affecting International Competitiveness of Zambia's Tourism Industry
}

\author{
Phillip Mutambo \\ School of International Trade and Economics, Jiangxi University of Finance and Economics, Nanchang, China
}

\section{Email address:}

phillipmutambo@ymail.com

\section{To cite this article:}

Phillip Mutambo. Empirical Analysis of Factors Affecting International Competitiveness of Zambia's Tourism Industry. International Journal of Psychological and Brain Sciences. Vol. 3, No. 1, 2018, pp. 7-17. doi: 10.11648/j.jppbs.20180301.12

Received: October 9, 2017; Accepted: October 24, 2017; Published: January 16, 2018

\begin{abstract}
Zambia's tourism industry has been developing noticeably for the last decade and it has become one of the major potential options for economy growth and diversification. Zambia is one such a country that offers unique attractive tourist sites yet it is not among the top 50 worldwide tourist destinations. This research was undertaken in order to empirically analyze factors affecting international competitiveness of the tourism industry in Zambia. The study used Trade Specialization Coefficient (TSC) as a measure of Tourism Industry Competitiveness in Zambia, and carried out an Empirical Analysis using econometric variables selected based on Porters Diamond Model of competitiveness. Using a Principal Component Analysis and Multiple Linear Regression Analysis, the study found that $78.3 \%$ of the International Competitiveness of Zambia's Tourism Industry can be explained by the identified variables in this study. This study concludes that there is need to develop a tourism development plan that streams down from a national to regional level, which will strengthen actions on the ground, leading to a coordination necessary to create opportunities for linking the tourism industry to policies going hand in hand with investment opportunities provided by modern information and telecommunications, which are necessary for improving the Internationational competitiveness of Tourism Industry.
\end{abstract}

Keywords: Tourism, International Competitiveness, Porters-Diamond-Model, Affecting Factors

\section{Introduction}

The country of Zambia in the southern part of Africa, has untapped environmental tourism reserves, talk of its richness in cultural and heritage sites, ample wildlife, rich water resources, harmony and serenity.

Zambia is one such a country that offers unique attractive tourist sites yet it is not among the top 50 worldwide tourist destinations. The country has a great landmass, an abundance of natural resources, a temperate climate and a stable political environment. This should make it an ideal tourist destination, yet out of the whole Sub Sahara Africa, Zambia only commands $0.6 \%$ of the total demand for tourism in the region (Tourism and Travel Council, 2008) [1]. All these resources are yet to be exposed to the outside world. The challenges to Zambia are how it can enhance awareness of its diverse tourism attractions and position the country as a tourism destination. This research has analyzed those factors that are affecting international competitiveness of tourism industry in Zambia.
The tourism sector in Zambia is accelerating at a fast pace. According to an Article published on July 13, 2016 by the ZambiaInvest. com [2]. There was a major and notable enhancement recorded in the tourism industry during the period of 2006-2010 where there was a significant increase in tourist numbers along with greater investment from the private sector. The target of 736,450 tourists was set by Fifth National Development Plan 2006-2010 and against this target, international tourist arrivals in Zambia averaged at 793,999 during that period.

The direct tourism earnings increased from USD174 million in 2005 to USD200 in 2009 against the targeted value of USD304 million by 2010. In addition, employment level increased to 25,860 in 2009 from 19,650 in 2005. During the tenure of 2006 to 2010; the contribution of tourism sector in GDP of Zambia remained constant at 3.1\%. In 2012, Zambia received 859,088 tourists compared to 920,299 recorded in 2011. 


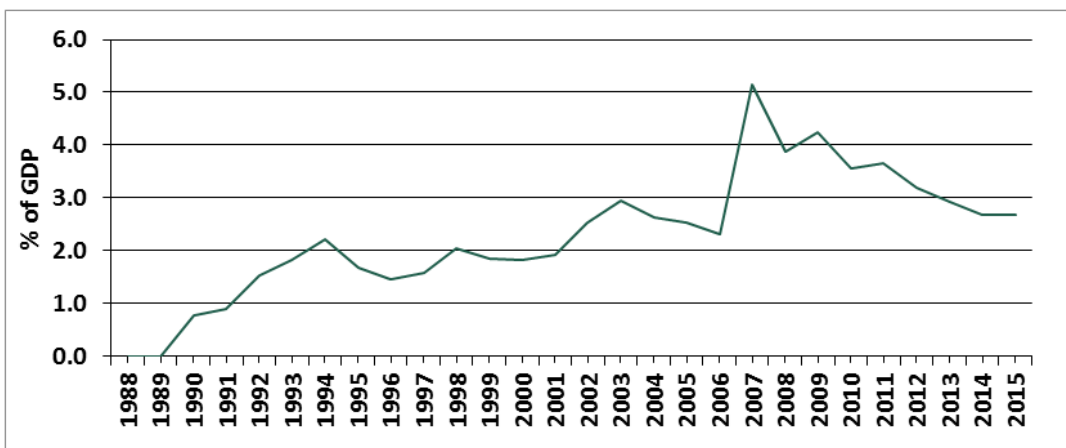

(Source: knoema.com/atlas/Zambia)

Figure 1. Tourism Direct Contribution to GDP -\% share.

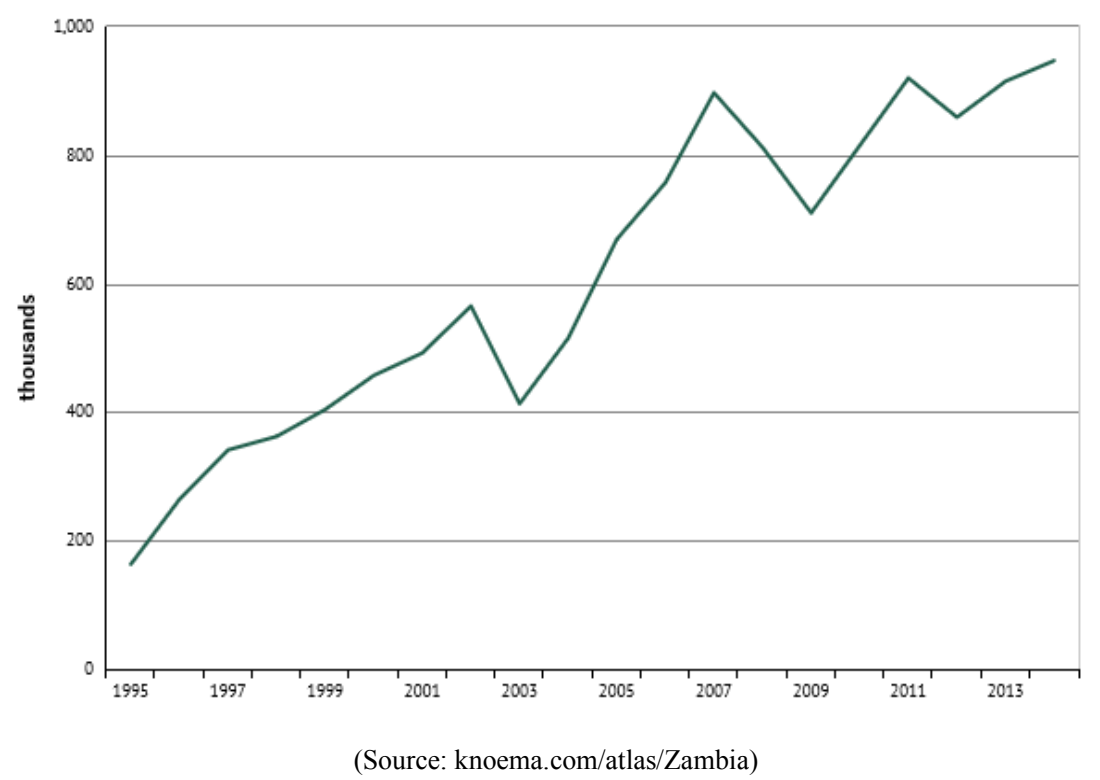

Figure 2. Arrivals non-resident tourists at national borders.

However there was a decline of $6.7 \%$ in the number of tourist arrival in 2014, despite that there is still growth anticipation in tourism industry by the Zambian government. The tourist sector structure of Zambia comprises of several types of enterprise including boarding hostels, lodges, hotels, tour operators, guesthouses and transport providers.

There are several large international franchises and chains in Zambia and also numerous small luxury lodges owned by foreigners and many small informal enterprises. Overall, Zambian tourism sector is dominated by small and medium sized operators that are well integrated vertically. Therefore these operators are reliant on overseas providers for various services such as flights, marketing and representation.

Over the time, Zambia has faced increased competition in tourism sector from its regional neighbors and this trend is expected to intensify in the future. Major competitors include Kenya, Tanzania, South Africa, Namibia, and Botswana. Political and economic problems in Zimbabwe however have suppressed competition from their tourist industry. However Zimbabwe is expected to recover easily as a competitor because their tourism sector is better developed and priced competitively.
But it should be noted that although there has been an increase in tourism sector of Zambia in the past decade, the sector is underperforming in comparison to other countries in the same region along with relation to its own potential. Despite having major tourism attractions, Zambia receives fewer tourists. The number of visitors is low, average visitor expenditure and length of stay is also limited. Botswana, neighboring country of Zambia has three times the number of tourists of Zambia. The overall average visitor stay of Zambia is also in decline. Zambia has around 34 game management areas and 19 national parks covering 33 percent of the country area but only five percent has been developed for tourism. This is the situation that is now being addressed by the government.

\section{Literature Review}

The review carried out in this research discovered that very little research has been carried out in Zambia on tourism industry in general; especially recent work on international competitiveness. An attempt has been made in this research to reveal the related literature; this research brings innovation 
and an addition to literature on Zambia's Tourism industry studies, as there is currently no empirical study on factors affecting international competitiveness of the tourism industry of Zambia. Furthermore general review of the related current literature, according to Chen et al, (2016) [3] shows that although there is a significant amount of research devoted to competitiveness, relatively few studies focus on evaluating competitiveness from the tourists' perspective.

Table 1 summarizes 87 articles that have been reviewed in this research, published from 1995 to 2015 in leading tourism and hospitality journals dealing with the concepts of international competitiveness.

Table 1. Published articles in leading tourism and hospitality journals.

\begin{tabular}{lll}
\hline Journal / Publisher & $\begin{array}{l}\text { Number of } \\
\text { Articles }\end{array}$ \\
\hline 1 & Annals of Tourism Research & 3 \\
2 & Journal of Sustainable Tourism & 4 \\
3 & Tourism Management & 13 \\
4 & Journal of Travel Research & 11 \\
5 & International Journal of Hospitality Management & 1 \\
6 & International Journal of Contemporary Hospitality & 16 \\
7 & Tourism Geographies & 2 \\
8 & Cornell Hospitality Quarterly & - \\
9 & Journal of Hospitality \& Tourism Research & 1 \\
10 & Leisure sciences & - \\
11 & Leisure Studies & - \\
12 & International Journal of Tourism Research & 4 \\
13 & Current Issues in Tourism & 10 \\
14 & Scandinavian Journal of Hospitality and Tourism & 2 \\
15 & Journal of Travel \& Tourism Marketing & 3 \\
16 & Journal of leisure research & - \\
17 & Tourism Economics & 14 \\
18 & Asia Pacific Journal of Tourism Research & 3 \\
TOTAL & & 87 \\
\hline
\end{tabular}

Source: J. Komšić, J. Dorčić: tourism destination competitiveness and online reputation

The analysis of published articles in the top 18 rated leading tourism and hospitality journals searched for the keywords "competitiveness" showed that in terms of "competitiveness", in total 87 full-length articles related to tourism and were found in different academic search database. According to the review of these articles, it was found that Ritchie and Crouch (2003) [4] were the first to commence development of a general model of destination competitiveness. The model linked together the macro and microenvironment factors and consists of five components, which are core resources and attractions, supporting factors and resources, destination policy, planning and development, destination management, and qualifying and amplifying determinants. Each of these five categories is further broken down into sets of indicator. Dwyer and Kim (2003) [5] introduced a holistic approach to the determinants and indicators of destination competitiveness. Their indicators were categorized into five subgroups: endowed resources, supporting factors, destination management, situational conditions, and demand factors.
Hanafiah et al (2015) [6] critically reviewed the Crouch and Ritchie (2003) and Dwyer and Kim (2003) models and stated that one of the greatest weaknesses of the models were the exhaustive lists of tourism destination factors without the mechanism for prioritizing these criteria. Hanafiah et al (2015) stated that the Crouch and Ritchie model does not pinpoint the causal relations in the tourism destination competitiveness model. Furthermore, the Dwyer and Kim (2003) model simplified and extended the previous model by not only integrating a number of determinants into extended categories, but also taking demand conditions into consideration and determining destination competitiveness development of the elements serving to create socioeconomic prosperity. Nevertheless, it is important to note that most of the selected determinants were not based on any empirical testing.

The World Economic Forum (WEF) Geneva published the Travel \& Tourism Competitiveness Report (TTCI) 2008 (World Economic Forum, 2008) [7] to explore the factors that drive the travel and tourism competitiveness of destinations. The TTCI is composed of 14 "pillars" of travel and tourism competitiveness, which include policy rules and regulations, environmental regulation, safety and security, health and hygiene, prioritization of travel and tourism, air transport infrastructure, ground transport infrastructure, tourism infrastructure, information and communication technology (ICT) infrastructure, price competitiveness in the travel and tourism industry, human resources, affinity for travel \& tourism, and natural and cultural resources.

In addition, Gomezelj and Mihalic (2008) [8] focused their research on environmental management using ingratiated resources, created resources, supporting factors, destination management, and situational condition and demand conditions to assess tourism competitiveness. Assaker (2011) adapted the CM framework and proposed the application of the economy, infrastructure, the environment and tourism as the significant determinants in explaining destination competitiveness [9]. Tseng and Chen (2013) constructed a framework for the evaluation of tourism destination competitiveness of cities in Taiwan using descriptive statistical analysis [10]. In contrary, Knezevic Cvelbar et al. (2015) developed productivity-related measures for destination competitiveness examination based on economic and tourism factors [11].

Cucculelli and Goffi (2015) [12] extend the Ritchie and Crouch (2000) model of destination competitiveness by introducing a set of sustainability indicators and testing their role in explaining the competitiveness of a tourism destination. The authors used the following indicators: sustainable tourism destination management, general infrastructures, events and activities, responsible tourist behavior, local empowerment in the tourism sector, destination marketing, quality of environmental and natural resources, gastronomy, historical and artistic feature, pricequality relationship, tourist accommodations, emphasis on maximizing local economic development. 


\section{Measuring International Competitiveness}

\subsection{Trade Specialization Coefficient (TSC)}

In order to measure the international competitiveness of tourism of countries, a number of concepts can be used, such as the concept of market share (MS), revealed comparative advantage (RCA), trade combining density index (TCD) and trade specialization coefficient (TSC). In this research a close attribute to trade specialization coefficient (TSC) has been used.

Trade Specialization Coefficient reflects the proportion of a certain industry's net exports to the total imports and exports of the industry in a country. It is jointly decided by the size of the import and export volume of the current year, domestic production and consumption, foreign production and consumption (Mu and Zhang, 2010) [13]. Trade Specialization Coefficient is also used as a tool to analyze the competitiveness of a certain industry in a country.

The formula of TSC is as follows:

$$
\text { (TSC) TSCij= (Xij-Mij) / (Xij+Mij). }
$$

In the formula, Xij means the export value of product $\mathrm{j}$ in country $i$; Mij means the import value of product $j$ in country i. The greater TSC value expresses the stronger export competitiveness of the country; the smaller TSC value expresses the weaker export competitiveness of the country; 0 means the competitiveness is near the average level. Trade specialization coefficient is always less than 1 and greater than -1 .

Trade Specialization Coefficient (TSC) has been used reflecting the proportion of tourism industry's net exports to the total imports and exports of the industry in Zambia. Trade Specialization Coefficient is used as a tool to analyze the competitiveness of a certain industry in a country. It is jointly decided by the size of the import and export volume of the current year, domestic production and consumption, foreign production and consumption ( $\mathrm{Mu}$ and Zhang, 2010: 8). Therefore in this research, a relationship of selected variable effect on TSC has been analyzed using multi linear regression analysis.

The formula of TSC is as follows:

$$
\text { (TSC) TSCij }=(X i j-M i j) /(X i j+M i j) \text {. }
$$

In the formula: Xij means the export value of product $\mathrm{j}$ in country $\mathrm{i}$; Mij means the import value of product $\mathrm{j}$ in country i. The greater TSC value expresses the stronger export competitiveness of the country; the smaller TSC value expresses the weaker export competitiveness of the country; 0 means the competitiveness is near the average level. Trade specialization coefficient is always less than 1. Table below shows Trade Specialization coefficient of the tourism industry in Zambia from 1997 to 2014.

Table 2. Calculated Trade Specialization Coefficients.

\begin{tabular}{llll}
\hline Year & Export of Tourism & Import of Tourism & TSC Indicator \\
\hline 1997 & 2.37 & 6.20 & -0.45 \\
1998 & 4.36 & 6.49 & -0.20 \\
1999 & 6.03 & 8.50 & -0.17 \\
2000 & 7.68 & 7.77 & -0.01 \\
2001 & 7.58 & 6.30 & 0.09 \\
2002 & 5.79 & 6.90 & -0.09 \\
2003 & 7.03 & 6.40 & 0.05 \\
2004 & 4.43 & 3.96 & 0.06 \\
2005 & 15.81 & 3.38 & 0.65 \\
2006 & 11.13 & 2.92 & 0.58 \\
2007 & 11.46 & 2.70 & 0.62 \\
2008 & 9.62 & 3.04 & 0.52 \\
2009 & 9.67 & 3.50 & 0.47 \\
2010 & 6.11 & 2.98 & 0.34 \\
2011 & 5.89 & 2.95 & 0.33 \\
2012 & 4.93 & 3.27 & 0.20 \\
2013 & 4.76 & 3.24 & 0.19 \\
2014 & 5.80 & 3.69 & 0.22 \\
\hline
\end{tabular}

Source: Calculated by Author using formula explained

\subsection{Porters' Diamond Model}

Porter concluded through the 'Diamond framework', which originally advocated the theory of competitiveness in the following years (1990a, 1997a, 1998b, 2000). Porter improved the understanding of the international competitiveness [14]. According to Peng (2004) this is the first multilevel theory to realistically connect firms, industries and nations. International competition at the firm level has transformed over the years because of the changing pattern of world trade, globalization of the world economy, rapid development and spread of ICT and the rise of transnational organizations [15]. These changes resulted in a revival of explanations for trade particularly at the level of individual industries (Porter 1990a, 2003). Porter introduced the concept of National Diamond (1990) that identifies the following: 


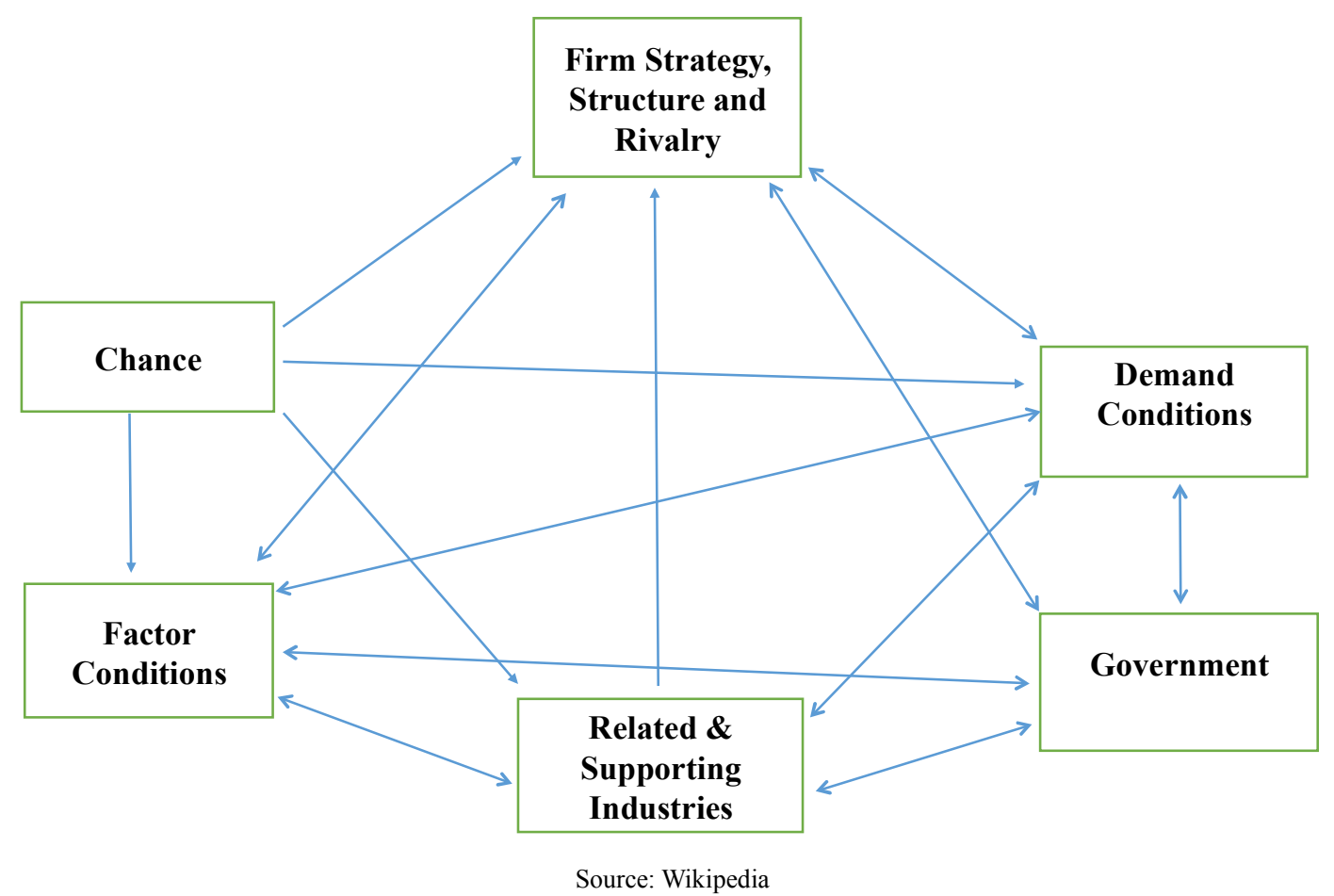

Figure 3. Porters Diamond Model.

\section{Factor Conditions}

Theoretically factor conditions include essential as well as advanced components. The fundamental factors incorporate geographical conditions, natural resources, infrastructure, Energy supply, basic labor force resources and financial market. The Advanced factors consist of technical equipment, talents, and skills, enhanced education, innovation and capital operations.

\section{Demand conditions}

These take into account domestic demand and international demand. It can be argued that the increase of national income of Zambia and the resident's income is bound to result in an improvement in domestic demand for tourism. GDP per capita growth rates can be used to analyze the dependence of tourism demand conditions whether on local or international. Likewise when modern home market purchasers weight firms to advance speedier and to make more propelled items than those of contenders, this will brag the international competitiveness of the industry in the long run.

Related and supporting industries

These can deliver inputs that are imperative for development and internationalization. These ventures give financially savvy inputs, however, they likewise take part in the redesigning procedure, therefore animating different organizations in the bind to improve.

Firm strategy, structure and rivalry

This constitute the fourth determinant of competitiveness. The way in which companies are created, set goals and are managed is important for success. But the presence of intense rivalry in the home base is also important; it creates pressure to innovate in order to upgrade competitiveness.

Government and Chance

Porter additionally includes that Government can impact each of the over four determinants of aggressiveness. Plainly government can impact the supply states of key creation elements, request conditions in the home market, and rivalry between firms. Government intercessions can happen at nearby, local, national or supranational level. As indicated by porter, Chance occasions are events that are outside of control of a firm. They are vital in light of the fact that they make discontinuities in which some increase competitiveness positions and some lose. The Porter Diamond Model is that these variables collaborate with each other to make conditions where advancement and enhanced competitiveness happens.

\section{Data Analysis}

The empirical analysis is based on variables selected based on porters model. The data was collected from the World Bank [17] and the Zambia statistics [18]. The 15 variables have been selected based on porter's model for competitiveness, which identifies determinants of competitiveness, which are those measuring local firm strategy and rivalry, variables measuring Factor (Input) Conditions, variables measuring Demand Conditions, and variables measuring Related and Supporting Industries. These variables have been examined over time for a selected period of time, which is from 1997 to 2014. 
Table 3. Economic Variables Chosen based on Porters Diamond Model.

\begin{tabular}{lll}
\hline Porters Diamond & Variable & Variable Description \\
\hline DEMAND & GDP & GDP at market prices (constant 2005 US\$) \\
DEMAND & INFL & Inflation, consumer prices (annual\%) \\
FACTOR & UEM & Unemployment, total (\% of total labor force) \\
FACTOR & NNI & Net national income per capita (constant 2005 US\$) \\
FACTOR & CPI & Consumer price index (2010 = 100) \\
FIRM STRATEGY & FDI & Foreign direct investment, net inflows (\% of GDP) \\
FIRM STRATEGY & CRED & Commercial banks and other creditors (INT, current US\$) \\
GOVT & EDEX & Adjusted savings: education expenditure (current US\$) \\
GOVT & GNE & Gross national expenditure (current US\$) \\
GOVT & HEX & Health expenditure per capita (current US\$) \\
GOVT & IMST & Improved sanitation facilities (\% of population with access) \\
GOVT & TROP & Trade Openness Index (Trade to GDP Ratio (\%)) \\
RELATED INDUSTRY & ICT & ICT goods imports (\% total goods imports) \\
RELATED INDUSTRY & INTE & Investment in telecoms with private participation \\
RELATED INDUSTRY & AIRT & Air transport, registered carrier departures worldwide \\
\hline
\end{tabular}

\subsection{Principal Component Analysis}

A principal component analysis was carried out in analyzing data, in order to ascertain whether the correlation among the 15 variables could be accounted for in terms of comparatively few latent variables. And to determine how many important components are present in the data, and further to analyze the extent to which these important components are able to explain the observed correlations between the variables. Relevant tables showing the work and analysis done have been included in this section.

Below are the Eigenvalues and the Scree Plot. The analysis results in the table are showing the importance of each of the 15 principal components (Variables). Only the first three variables have eigenvalues over 1.00 , this concludes that a three-factor solution is to be adequate in determining which factors affect the international competitiveness of the tourism industry in Zambia. And together these explain over 84.362\% of the total variability in the data.

Table 4. Below is the Eigenvalues and the Scree Plot.

\begin{tabular}{|c|c|c|c|c|c|c|c|c|c|}
\hline \multicolumn{10}{|c|}{ Total Variance Explained } \\
\hline \multirow{2}{*}{ Component } & \multicolumn{3}{|c|}{ Initial Eigenvalues } & \multicolumn{3}{|c|}{ Extraction Sums of Squared Loadings } & \multicolumn{3}{|c|}{ Rotation Sums of Squared Loadings } \\
\hline & Total & $\%$ of Variance & Cumulative\% & Total & $\%$ of Variance & Cumulative\% & Total & \% of Variance & Cumulative\% \\
\hline 1 & 9.998 & 66.655 & 66.655 & 9.998 & 66.655 & 66.655 & 9.013 & 60.083 & 60.083 \\
\hline 2 & 1.446 & 9.642 & 76.297 & 1.446 & 9.642 & 76.297 & 2.037 & 13.577 & 73.661 \\
\hline 3 & 1.210 & 8.065 & 84.362 & 1.210 & 8.065 & 84.362 & 1.605 & 10.701 & 84.362 \\
\hline 4 & .762 & 5.079 & 89.441 & & & & & & \\
\hline 5 & .623 & 4.152 & 93.593 & & & & & & \\
\hline 6 & .454 & 3.024 & 96.617 & & & & & & \\
\hline 7 & .255 & 1.701 & 98.318 & & & & & & \\
\hline 8 & .115 & .764 & 99.082 & & & & & & \\
\hline 9 & .059 & .394 & 99.476 & & & & & & \\
\hline 10 & .038 & .251 & 99.727 & & & & & & \\
\hline 11 & .024 & .158 & 99.885 & & & & & & \\
\hline 12 & .014 & .093 & 99.978 & & & & & & \\
\hline 13 & .002 & .015 & 99.993 & & & & & & \\
\hline 14 & .001 & .006 & 100.000 & & & & & & \\
\hline 15 & 4.349E-05 & .000 & 100.000 & & & & & & \\
\hline
\end{tabular}

The middle part of the table is showing the eigenvalues and percentage of variance explained for just the three factors of the initial solution that are regarded as important. The first factor of the initial solution is much more important than the second and third. However, in the right hand part of the table, the eigenvalues and percentage of the variance explained for the three rotated factors are displayed. The effect of rotation was to spread the importance more or less equally between the three rotated factors.

The conclusion in the total variance explained above was supported by the scree plot below, which is actually displaying the same data visually. This is also showing that a three-factor solution was adequate in determining which factors affect the international competitiveness of the tourism industry in Zambia.

The Rotated Component Matrix was further carried out. In the table 5 below shows the factor loadings that resulted from Varimax rotation. The results show the three rotated components (factors), which are just as good as the initial factors (selected variables) in explaining and reproducing the observed correlation matrix. The table below shows to which component the variables belong based on the highest positive and negative loadings. 


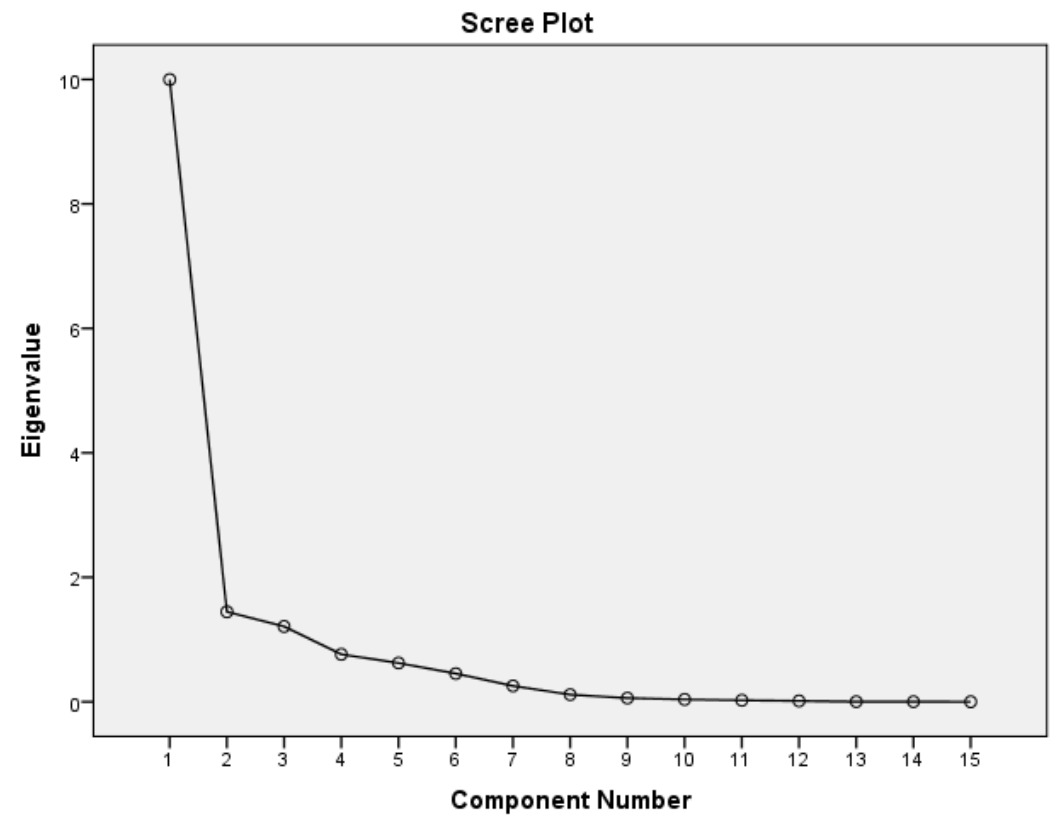

Figure 4. Scree Plot showing three factor solution.

Table 5. Rotated Component Matrix.

\begin{tabular}{llll}
\hline & Component & & \\
\cline { 2 - 4 } & $\mathbf{1}$ & $\mathbf{2}$ & $\mathbf{3}$ \\
\hline GDP & .953 & & \\
INFL & -.906 & & .933 \\
UEM & & & \\
NNI & .915 & & \\
CPI & .959 & .777 & \\
FDI & & & \\
CRED & .828 & & \\
EDEX & .961 & & \\
GNE & .949 & & \\
HEX & .962 & & \\
IMST & .959 & & \\
TROP & .663 & & \\
ICT & & & \\
INTE & .669 & & \\
AIRT & & & \\
\hline
\end{tabular}

Table 6. Component Transformation Matrix.

\begin{tabular}{llll}
\hline Component & $\mathbf{1}$ & $\mathbf{2}$ & $\mathbf{3}$ \\
\hline 1 & .942 & .306 & -.138 \\
2 & .171 & -.082 & .982 \\
3 & -.289 & .948 & .130 \\
\hline
\end{tabular}

The Component Transformation Matrix is showing information about the extent to which the factors have been rotated.

\subsection{Linear Regression Analysis}

Regression model has been used in analyzing the results of the principal component analysis; the research has used this model and assumed that the relationship between the independent variables identified as being the three components and the international competitiveness of tourism is linear, other factors held constant. Therefore international competitiveness of tourism industry is a function of the variables reduced into three components from the Principal Component Analysis. The dependent variable being Trade Specialization Coefficient (TSC) measuring the international competitiveness of tourism industry in Zambia, in the function below:

$\mathrm{Y}=\mathrm{f}$ (Ind_Var1 + Ind_Var2 + Ind_Var3) where, F= function

$\mathrm{Y}=\mathrm{TSC}$ (Trade Specialization Coefficient)

Ind_Variable 1 (Component 1: Table 5 make up of 11 variables $)=(\mathrm{GDP}+\mathrm{INFL}+\mathrm{NNI}+\mathrm{CPI}+\mathrm{CRED}+\mathrm{EDEX}+\mathrm{GNE}+\mathrm{H}$ $\mathrm{EX}+\mathrm{IMST}+\mathrm{TROP}+\mathrm{AIRT})$

Ind Variable 2 (Component 2: Table 5 make up of 2 variables $)=(\mathrm{FDI}+\mathrm{INTE})$

Ind_Variable 3 (Component 3: Table 5 make up of two variable $)=(\mathrm{UEM}+\mathrm{ICT})$

The dependent variable was Trade Specialization Coefficient (TSC), from the descriptive statistics below, showing that the mean value of rate of change in TSC has been $18.9 \%$ from 1997 to 2014 .

Table 7. Descriptive Statistics.

\begin{tabular}{llll}
\hline \multicolumn{4}{l}{ Descriptive Statistics } \\
\hline & Mean & Std. Deviation & N \\
\hline TSC & .1889 & .31014 & 18 \\
Ind_Var1 & .9347 & .02193 & 18 \\
Ind_Var2 & 3.8662 & .23833 & 18 \\
Ind_Var3 & .6245 & .02985 & 18 \\
\hline
\end{tabular}

The figure below shows the relationship between the dependent (TSC) and the independent variables using the correlation coefficient. The correlation matrix is also showing the most significant factors in the list of the independent variables. 
Table 8. Table of Correlations.

\begin{tabular}{llllll}
\hline & & TSC & Ind_Var1 & Ind_Var2 & Ind_Var3 \\
\hline & TSC & 1.000 & .623 & .812 & -.016 \\
Pearson Correlation & Ind_Var1 & .623 & 1.000 & .601 & -.403 \\
& Ind_Var2 & .812 & .601 & 1.000 & -.310 \\
& Ind_Var3 & -.016 & -.403 & -.310 & 1.000 \\
Sig. (1-tailed) & TSC & & .000 & .475 \\
& Ind_Var1 & .003 & .003 & .004 & .049 \\
& Ind_Var2 & .000 & .004 & .105 & .105 \\
N & Ind_Var3 & .475 & .049 & 18 & 18 \\
& TSC & 18 & 18 & 18 & 18 \\
& Ind_Var1 & 18 & 18 & 18 & 18 \\
& Ind_Var2 & 18 & 18 & 18 & 18 \\
\hline
\end{tabular}

The above table shows the results of the study, which indicated that TSC is strongly correlated at 0.623 with "Ind_Var1" (GDP; INFL; NNI; CPI; CRED; EDEX; GNE;
HEX; IMST; TROP; AIRT). Further it is strongly correlated with "Ind_Var2" (FDI; INTE) at 0.812, and lastly shows negative correlated with Ind_Var3 (UEM; ICT) at -0.016 .

Table 9. Model Summary.

\begin{tabular}{|c|c|c|c|c|c|c|c|c|c|}
\hline \multirow{2}{*}{ Model } & \multirow{2}{*}{$\mathbf{R}$} & \multirow{2}{*}{ R Square } & \multirow{2}{*}{$\begin{array}{l}\text { Adjusted R } \\
\text { Square }\end{array}$} & \multirow{2}{*}{$\begin{array}{l}\text { Std. Error of the } \\
\text { Estimate }\end{array}$} & \multicolumn{5}{|l|}{ Change Statistics } \\
\hline & & & & & R Square Change & F Change & df1 & df2 & Sig. F Change \\
\hline 1 & $.885^{\mathrm{a}}$ & .783 & .737 & .15920 & .783 & 16.839 & 3 & 14 & .000 \\
\hline
\end{tabular}

The above table shows the $\mathrm{R}$ Square of 0.783 , which indicates that $78.3 \%$ of Trade Specialization Coefficient, which is measuring the International Competitiveness of Zambia's Tourism Industry, can be explained by the independent variables identified and tested in this analysis.
$78.3 \%$ is quite sufficient in this case.

The ANOVA table below shows how well the regression equation fits the data, it is predicting the dependent variable as shown below:

Table 10. ANOVA.

\begin{tabular}{llllll}
\hline Model & Sum of Squares & df & Mean Square & F & Sig. \\
\hline \multirow{2}{*}{1} & Regression & 1.280 & 3 & .427 & 16.839 \\
& Residual & .355 & 14 & .025 & \\
& Total & 1.635 & 17 & & \\
\hline
\end{tabular}

This table indicates that the regression model predicted the dependent variable significantly well. The table above under the "Regression" row on the "Sig." column. This indicates the statistical significance of the regression model that was run. Here, $p<0.000$, which is less than 0.05 , and indicates that, overall, the regression model statistically significantly predicts the outcome variable, meaning it is a good fit for the data.

The Coefficients table below shows the necessary information used in this study in predicting the International Competitiveness of tourism from the selected variables, as well as to determine whether these variables contributes statistically significantly to the model (by looking at the "Sig." column).

Table 11. Coefficients.

\begin{tabular}{|c|c|c|c|c|c|c|c|c|c|}
\hline \multirow{2}{*}{ Model } & \multicolumn{2}{|c|}{ Unstandardized Coefficients } & \multirow{2}{*}{$\begin{array}{l}\text { Standardized Coefficients } \\
\text { Beta }\end{array}$} & \multirow{2}{*}{$\mathbf{t}$} & \multirow{2}{*}{ Sig. } & \multicolumn{2}{|c|}{ 95.0\% Confidence Interval for B } & \multicolumn{2}{|c|}{ Collinearity Statistics } \\
\hline & B & Std. Error & & & & Lower Bound & Upper Bound & Tolerance & VIF \\
\hline \multirow{4}{*}{ (Constant) } & -9.953 & 2.321 & & -4.288 & .001 & -14.932 & -4.975 & & \\
\hline & 4.616 & 2.298 & .326 & 2.008 & .064 & -.314 & 9.546 & .587 & 1.705 \\
\hline & .938 & .204 & .721 & 4.606 & .000 & .501 & 1.374 & .633 & 1.579 \\
\hline & 3.526 & 1.420 & .339 & 2.484 & .026 & .481 & 6.571 & .830 & 1.204 \\
\hline
\end{tabular}

The values in the "B" column under the "Unstandardized Coefficients" column, as shown below: The "B" coefficients shows by how much effect on international competitiveness for a single unit increases in each variable. Like so, 1 point increase on the independent variable (Ind_Var1) corresponds to 4.616 points increase on the international competitiveness of tourism measured by the TSC, and 1 point increase on the independent variable (Ind Var2) corresponds to 0.938 increase and lastly 1 point increase on the independent variable (Ind_Var3) corresponds to 3.526 increase on the TSC measuring international competitiveness of tourism industry in Zambia.

\subsection{Discussion of Linear Regression Analysis Results}

The Multiple Linear Regression Analysis carried out in this study indicated that the value of $\mathrm{R}$ Square is 0.783 , which indicates that $78.3 \%$ of the International Competitiveness of Zambia's Tourism Industry can be 
explained by the independent variables identified and tested in this study. $78.3 \%$ is quite sufficient in this case to support the validity of this study.

The Coefficients table showed that 1-point increase on the independent variable (Ind_Var1) corresponds to 4.616 points increase on the international competitiveness of tourism in Zambia. This variable is a product of the principal component analysis of data reduction, which is a makeup of 11 different independent variables that have been reduced into one component named as Independent Variable 1 (Ind_Var1).

The variables making up this composition are as follows; Gross Domestic Product (GDP), Inflation (INF), Net National Income (NNI), Consumer Price Index (CPI), Commercial Banks and Creditors (CRED), Education Expenditure (EDEX), Gross National Expenditure (GNE), Health Expenditure (HEX), Improved Sanitation Facilities (IMST), Trade Openness (TROP) and Air transport registered carrier departures worldwide (AIRT). All these variables were reduced into one component in principal component analysis with highest loadings on Component 1 explained in the rotated component table under principal component analysis section. What this explains is that all these variables have the same positive correlation of 4.616 with TSC, which means that these variables are statistically significant together and the effect can be explained together. As the correlation coefficient is positive at 4.616 it explains that International Competitiveness of Tourism Industry in Zambia was found to be responsive to these variables, this suggests that these are empirical factors affecting international competitiveness of the tourism industry in Zambia. The 1point increase on these independent variables will correspond to 4.616 points increase on the international competitiveness of tourism measured by the TSC.

The Coefficients table also shows the Independent Variable 2 (Ind_Var2) which is also a named variable from the principal component analysis, make up of two initial variables "FDI; INTE" which are Foreign Direct Investment and Investment in Telecoms with private participation. The coefficients table shows that 1-point increase on the independent variable (Ind_Var2) corresponds to 0.938 increases in the International Competitiveness of Tourism Industry in Zambia.

Zambia lacks the necessary technology, which FDI is regarded as a way of filling up the gap in this study. FDI in tourism is concentrated in activities such as hotel accommodation, restaurants and car rentals, however in Zambia there is little FDI in tour operators, reservation systems, travel agencies and airlines. This is because Zambia is a developing country with a developing market, most of the global hotel brands and tourism investment related wish to have a presence in established markets providing leisure and business tourism and as such the majority of these occur in developed countries. On the other hand, Investment in telecoms with private participation "INTE" has been found to be significant in this study and positive effect on International Competitiveness of Tourism in Zambia. The increasing competitiveness in the global tourism market encourages tourism operators to investment more in promotion, resources, knowledge and quality in order to achieve satisfactory growth. Therefore, it is extremely important to be in touch with the latest technological trends and have the knowledge required to effectively respond to the challenges of global competition. Internet technology provides high-quality and efficient operations in all economic sectors, including the tourism industry.

Lastly the Coefficients table shows the Independent Variable 3 (Ind_Var3), which is also a result of data reduction from principal component analysis, this variable is a makeup of Unemployment and Information Communication Technology (UEM; ICT). The results shows that 1 point increase on the independent variable (Ind_Var3) corresponds to 3.526 increase on the TSC measuring international competitiveness of tourism industry in Zambia.

\section{Conclusion and Policy Recommendation}

\subsection{Conclusion}

The general objective of this research was to investigate the current situation of the tourism industry in Zambia and analyze the factors affecting the international competitiveness of tourism industry. This research has provided a good start up literature on Zambia's tourism industry competitiveness, and it will help further research in this area.

The study carried out an Empirical Analysis using the variables selected based on Porters Diamond Model for competitiveness, which identifies four determinants which are those measuring local firm strategy and rivalry, variables measuring Factor (Input) Conditions, variables measuring Demand Conditions, and variables measuring Related and Supporting Industries. The data for these variables was obtained from the World Bank database and the Zambia central statistics office; this was empirically analyzed using a principal component analysis and linear regression analysis model.

The Multiple Linear Regression Analysis carried out in this study indicated that $78.3 \%$ of the International Competitiveness of Zambia's Tourism Industry could be explained by the independent variables, which were tested in this study. These factors are significant in this study with positive effect on International Competitiveness of Tourism in Zambia. The increasing competitiveness in the global tourism market encourages tourism operators and governments to investment more in promotion, resources, knowledge and quality in order to achieve satisfactory growth. Therefore, it is extremely important to be in touch with the latest technological trends and have the knowledge required to effectively respond to the challenges of global competition.

\subsection{Policy Recommendations}

Tourism continues to be an important economic sector for Zambia capable of attracting foreign direct investments and supporting the much-needed economic diversification. Recognizing the fact that this diversification implementation 
will require an integrated open-ended process engaging government at all levels, international organizations, businesses, and consumers, the recommendations in this empirical analysis of factors affecting international competitiveness of tourism industry are structured in a form of a simplified life cycle of the tourism value chain.

There is need to develop a tourism plan that streams down from a national to regional development plan that will strengthen action on the ground and build the skills and resources that will improve the international competitiveness of Zambia's tourism industry. This coordination is important in improving planning as considering these connections will create opportunities for linking all the regional tourist attractions. Tourism planning should be closely linked to policies for international competitiveness, which will define conditions necessary to serve as basis for industry development.
There is need for collaboration with tourism industry key players to promote investment in sustainable infrastructure, through financing from national and international organizations dealing with investments in infrastructure related to tourism.

Tourism promotion and marketing should involve the quadrants of international competitiveness as a primary basis for influencing consumer choices. This should go hand in hand with policies opening up investment opportunities provided by modern information and telecommunications, which will not only make it easy to understand behavior of tourists through linkages using networks, media and other communication systems. But this will also help government and other businesses to set baseline for measuring targets, review progress and report towards the achievement of international competitiveness of the tourism industry.

\section{Appendix}

Table 12. Selected Variables Based on Porters Model.

\begin{tabular}{|c|c|c|c|c|c|c|c|}
\hline Year & GDP & INFL & UEM & NNI & CPI & FDI & CRED \\
\hline 1997 & 5694070030 & 24.41872157 & 14.5 & 474.6608728 & 11.98163155 & 4.819577319 & 30000 \\
\hline 1998 & 5672105370 & 24.45845635 & 12 & 453.799867 & 14.91215368 & 5.596883537 & 26000 \\
\hline 1999 & 5935869034 & 26.78769668 & 12.19999981 & 451.938697 & 18.90677617 & 4.758670801 & 4062000 \\
\hline 2000 & 6167209016 & 26.03041179 & 12.89999962 & 447.9386929 & 23.82828787 & 3.379914273 & 3605000 \\
\hline 2001 & 6495111398 & 21.39378218 & 14.5 & 469.586865 & 28.92605987 & 3.541352382 & 3305000 \\
\hline 2002 & 6787782053 & 22.23334464 & 14.69999981 & 494.6749978 & 35.35729045 & 7.11494945 & 4395000 \\
\hline 2003 & 7259191744 & 21.40157839 & 15.19999981 & 504.4538666 & 42.92430868 & 7.078974814 & 4286000 \\
\hline 2005 & 8331870169 & 18.3244397 & 15.89999962 & 486.7565338 & 59.91577845 & 4.284032189 & 28173000 \\
\hline 2006 & 8990395734 & 9.019572472 & 15.60000038 & 496.8288233 & 65.31992551 & 4.827128722 & 23023000 \\
\hline 2007 & 9741312805 & 10.6573496 & 15.19999981 & 513.280524 & 72.28129833 & 9.418111673 & 22658000 \\
\hline 2008 & 10498592313 & 12.44557935 & 15.60000038 & 600.7707282 & 81.27712466 & 5.240508113 & 24312000 \\
\hline 2009 & 11466599106 & 13.39525463 & 14.80000019 & 586.1043735 & 92.16440247 & 4.532779776 & 23651000 \\
\hline 2010 & 12647453081 & 8.501761334 & 13.19999981 & 631.7546686 & 100 & 8.533199545 & 18268000 \\
\hline 2011 & 13449105083 & 6.429396811 & 13.19999981 & 683.3696291 & 106.4293968 & 4.670962309 & 35091000 \\
\hline 2013 & 15317976308 & 6.977676055 & 13.10000038 & 750.7240588 & 121.3427317 & 7.828996557 & 17618000 \\
\hline 2014 & 16237054898 & 7.811954417 & 13.30000019 & 750.7240588 & 130.8219706 & 5.570779527 & 33400000 \\
\hline
\end{tabular}

Table 12. Continue.

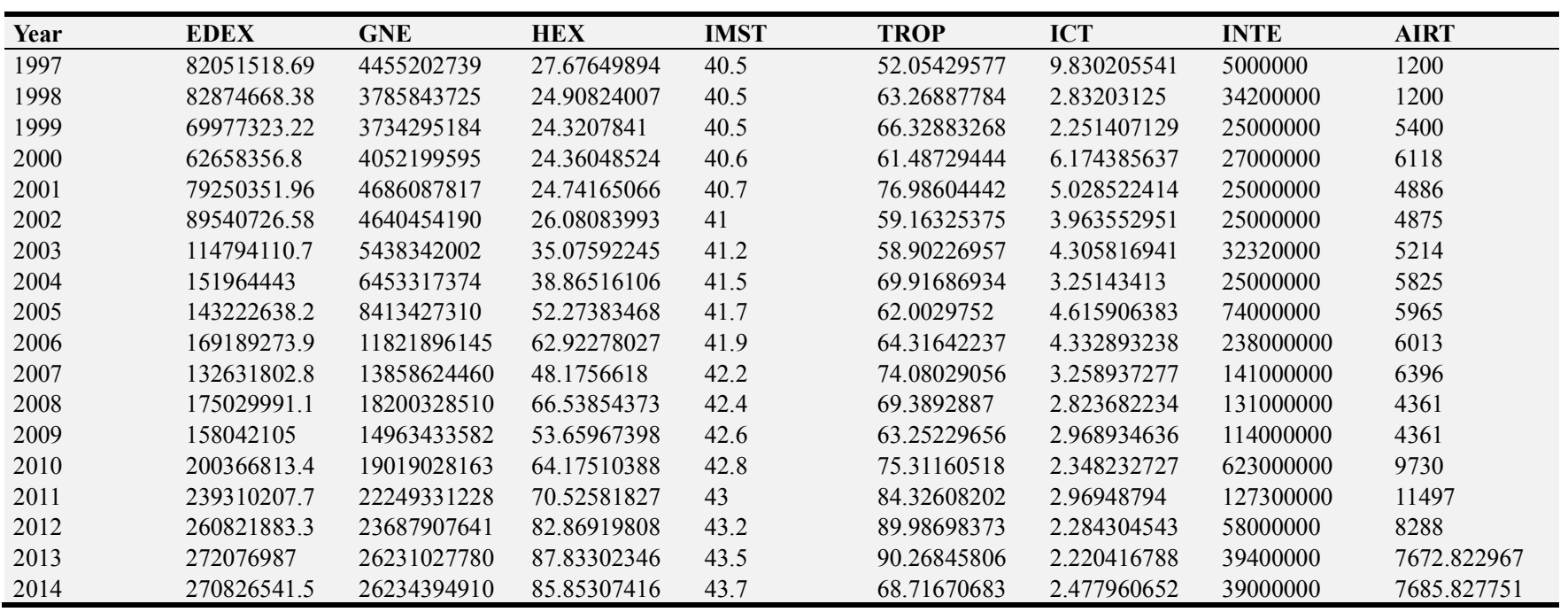

Source: Compiled by author from World Bank data 


\section{References}

[1] Tourism and Travel Council. WTTC, (2008). Tourism Satellite Account Publication.

[2] ZambiaInvest.com, July 13, 2016 "Zambia Tourism" http://www.zambiainvest.com/tourism

[3] Chen, C. M., Chen, S. H., Lee, H. T. and Tsai, T. H. (2016), "Exploring destination resources and competitiveness-A comparative analysis of tourists' perceptions and satisfaction toward an island of Taiwan", Ocean \& Coastal Management, Vol. 119, pp. 58-67.

[4] Ritchie, J. R. B., Crouch, G. I. (2003). The Competitive Destination: A Sustainable Tourism Prospective, CABI Publishing.

[5] Dwyer, L. and Kim, C. (2003), "Destination competitiveness: Determinants and indicators", Current issues in Tourism, Vol. 6, No. 5, pp. 369-414.

[6] Hanafiah, M. H., Hemdi, M. A., Ahmad, I. (2015), "Reflections on Tourism Destination Competitiveness (TDC) Determinants", Advanced Science Letters, Vol. 21, No. 5, pp. 1571-1574.

[7] Travel \& Tourism Competitiveness Report (TTCI) 2008 (World Economic Forum, 2008, 25).

[8] (Gomezelj and Mihalic, 2008). Destination competitivenessApplying different models, the case of Slovenia. Faculty of Management Koper, University of Primorska, Cankarjeva 5, 6000 Koper, Slovenia Faculty of Economics, University of Ljubljana, Kardeljeva pl. 17, 1000 Ljubljana, Slovenia.

[9] Assaker, G., Vinzi, V. E. and O’Connor, P. (2011), "Extending a tourism causality network model: A crosscountry, multigroup empirical analysis", Tourism and Hospitality Research, Vol. 11, No. 4, pp. 258-277.

[10] Tseng, H. P. and Chen C. H. (2013), "Exploration of destination competitiveness framework - city as a destination", Complex, Intelligent, and Software Intensive Systems (CISIS), 2013 Seventh International Conference, pp. 673-676.

[11] Knezevic Cvelbar, Dwyer, L, Koman, M. and Mihalic, T. (2015), "Drivers of Destination Competitiveness in Tourism: A Global Investigation", Journal of Travel Research, pp. 1-10.

[12] Cucculelli, M. and Goffi, G. (2015), "Does sustainability enhance tourism destination competitiveness? Evidence from Italian Destinations of Excellence", Journal of Clear Production, pp. 1-13.

[13] Mu Quan and Zhang Shiqiu (2010): Factor Analysis of International Competitiveness of the Iron and Steel Industry in China, Peking University, Beijing, p. 8, http://www.kadinst.hku.hk/sdconf10/Papers_PDF/p163.pdf

[14] Porter (1998), "The Competitive Advantage: Creating and Sustaining Superior Performance". NY: Free Press.

[15] Peng (2004) "Global Strategy". M. W. Peng, J. Tan, \& T. Tong, 2004 www.utdallas.edu/ zlin/Chapter\%202-BPS4305.ppt

[16] Porter, M. \& van der Linde, C. (1995). Green and competitive. Harvard Business Review, September-October, 120-134.

[17] The World Bank (2012). World Development Indicators https://data.worldbank.org

[18] Zambia Statistics Office http://zamstats.gov.zm 